\title{
ANALISIS PENERAPAN SISTEM INFORMASI AKUNTANSI DALAM MENUNJANG PENGENDALIAN INTERNAL PEMBIAYAAN KREDIT USAHA MIKRO PADA PT BANK SULUTGO
}

\author{
Roslin Sawori ${ }^{1}$, Jenny Morasa ${ }^{2}$, Steven J Tangkuman ${ }^{3}$ \\ ${ }^{1,2,3}$ Jurusan Akuntansi, Fakultas Ekonomi dan Bisnis, Universitas Sam Ratulangi, Jl. Kampus Bahu, Manado, \\ 95115, Indonesia \\ E-mail : sawori_roslin@yahoo.com
}

\begin{abstract}
The credit provided by PT SulutGo Bank is very helpful to the community in obtaining its business capital. The problems that often arise in credit are bad debts, and this risks the smooth operation of the bank. This research aims to determine the application of accounting information systems in supporting the internal control of micro business credit financing at PT SulutGo Bank to get a clear picture of this application. This research uses descriptive analysis method. The type of data used in this research is qualitative data. The result showed that the application of the micro finance credit information systems at PT SulutGo Bank has been carried out well and has supported the internal control of micro business credit financing. This is indicated by elements of the accounting information system that supports each component of internal control.
\end{abstract}

Keywords: application of accounting information system, internal control

\section{PENDAHULUAN}

Sistem informasi akuntansi dan pengendalian internal yang baik diharapkan dapat menjamin proses pemberian kredit tersebut terlaksana dengan baik dan terhindar dari kesalahan atau penyelewengan. Pengendalian internal tidak bertujuan untuk menghilangkan semua kemungkinan kesalahan yang akan terjadi, namun pengendalian internal yang baik akan dapat memperkecil kemungkinan terjadinya kesalahan selama operasional perusahaan tersebut,meskipun terjadi kesalahan maka akan segera diketahui dan dapat segera diperbaiki. Fungsi dari sistem informasi akuntansi terhadap sebuah organisasi adalah untuk mengumpulkan dan menyimpan berbagai macam data mengenai aktivitas dan transaksi dari perusahaan dan kemudian data tersebut diproses menjadi sebuah informasi yang dapat digunakan oleh manajemen dalam mengambil suatu keputusan yang diperlukan.

Pemberian kredit adalah suatu proses yang membutuhkan analisis serta pertimbangan dari para pengambil keputusan yang dalam hal ini adalah komite pemutus kredit. Hal ini untuk menghindari adanya kemungkinan kerugian yang dialami oleh bank sebagai akibat dari adanya debitur yang tidak memenuhi tanggung jawabnya sesuai dengan perjanjian yang telah disepakati bersama. Suatu kredit jadi bermasalah apabila salah satu pihak bersikap atau bertindak lalai dalam melaksanakan tanggung jawabnya, baik itu dari pihak debitur maupun dari pihak kreditur yang dalam hal ini adalah pihak bank. Sistem informasi akuntansi adalah suatu sistem yang digunakan untuk memproses sebuah data transaksi yang akan menghasilkan sebuah informasi untuk membantu para pengambil keputusan.

Pemberian kredit pada calon debitur PT Bank SulutGo melalui beberapa proses yaitu diawali dengan pengajuan permohonan kredit oleh calon debitur kemudian dilakukan registrasi dan dilakukan analisa kredit ketika calon debitur telah melengkapi persyaratan yang ditetapkan oleh pihak bank. Karena bagi masyarakat manado dan sekitarnya khususnya untuk Usaha Mikro mereka lebih memilih dana pinjaman dari bank dalam membantu memajukan 
usaha mereka, oleh karena itu permintaan kredit dari masyarakat masih menjadi semakin besar.

Kredit usaha mikro adalah salah satu jenis kredit yang disalurkan oleh PT Bank SulutGo kepada masyarakat yang sasarannya adalah masyarakat yang bergerak dalam bidang usaha mikro. Meskipun perkreditan pada PT Bank SulutGo masih dikuasai oleh kredit konsumtif, tetapi saat ini pihak PT Bank SulutGo sedang berusaha meningkatkan penyaluran kredit produktif salah satunya Kredit usaha mikro. Namun, kredit usaha mikro masih menguasai sebagian besar kredit produktif pada PT Bank SulutGo terutama dari jumlah pemohon kreditnya. Dengan makin besarnya kredit yang diberikan oleh PT Bank SulutGo maka resiko kredit macet yang ditimbulkan akan makin besar pula apabila penerapan sistem informasi akuntansi tidak dilaksanakan secara baik serta pengendalian internal yang kurang baik dalam penerapannya. Dalam hal ini penelitian dilakukan pada PT Bank SulutGo. Penelitian ini bertujuan untuk menganalisis bagaimana penerapan sistem informasi akuntansi dalam pembiayaan kredit usaha mikro dapat menunjang pengendalian internal pembiayaan kredit usaha mikro yang ada pada PT Bank SulutGo.

\section{TINJAUAN PUSTAKA}

Akuntansi. Akuntansi merupakan suatu sistem informasi yang mempunyai tujuan untuk menyiapkan suatu laporan keuangan bagi pihak yang berkepentingan mengenai kondisi keuangan dari suatu perusahaan, Reeve et al., (2013 : 9).

Sistem Informasi Akuntansi. Sistem informasi akuntansi merupakan sebuah sistem yang berfungsi untuk memproses sebuah data transaksi untuk menghasilkan suatu informasi yang mempunyai manfaat dalam perencanaan dan pengendalian serta dalam proses pengoperasian bisnis, Krismiaji (2015 : 4).

Unsur-unsur Sistem Informasi Akuntansi. Romney dan Steinbart (2014 : 11) berpendapat bahwa sistem informasi akuntansi mempunyai beberapa komponen yaitu orang atau menusia yang mengopeerasikan atau menggunakan sistem tersebut; adanya prosedur yang digunakan dalam pengumpulan, pemrosesan, serta penyimpanan data; data-data mengenai perusahaan dan semua aktivitas bisnis perusahaan; sistem atau perangkat lunak yang dimiliki oleh perusahaan dalam mengolah data transaksi; infrastruktur dari teknilogi informasi berupa komputer dan telepon yang dimiliki perusahaan digunakan dalam penerapan sistem; serta pengendalian internal dan pengukuran keamanan.

Tujuan dan fungsi Sistem Informasi Akuntansi. Tujuan dari sistem informasi akuntansi menurut Romney dan Steinbart (2014 : 11) yaitu: mengumpulkan serta menyimpan semua data mengenai aktivitas dari perusahaan yang menggunakan sistem tersebut berupa sumber daya yang ada dalam perusahaan serta semua aktivitas bisnis perusahaan tersebut; memproses sebuah data sehingga menjadi sebuah informasi yang membantu manajemen dalam perencanaan, pengendalian, serta pengevaluasian semua aktivitas dari sumber daya yang ada dalam perusahaan; serta membantu manajemen dalam menjalankan pengendalian yang baik dalam hal mengamankan aset serta data-data dari perusahaan. Fungsi penting sebuah sistem informasi akuntansi dalam organisasi adalah sebagai berikut (Krismiaji, 2015 : 26).

1. Memproses data transaksi dari suatu perusahaan secara efektif serta efisien.

2. Menghasilkan informasi yang berguna bagi manajemen dalam pembuatan atau dalam pengambilan keputusan yang tepat.

3. Melakukan pengawasan yang baik dan memadai untuk dapat menjamin bahwa semua informasi yang dihasilkan dapat dijamin kebenarannya serta dapat dipercaya, dapat menjamin semua aktivitas bisnis telah dilaksanakan secara baik serta telah sesuai dan sejalan dengan tujuan manajemen dan peraturan yang dibuat oleh perusahaan, dan dapat melindungi semua aset dari perusahaan termasuk semua data yang dimiliki oleh perusahaan. 
Pengendalian Internal. Pengendalian internal merupakan sebuah prosedur yang dilaksanakan oleh semua pihak dalam perusahaan baik oleh pimpinan, manajemen maupun karyawan dalam memberikan suatu kepastian mengenai pencapaian tujuan perusahaan, Widjadja (2013).

Prinsip-prinsip Pengendalian Internal. Kerangka pengendalian internal COSO (2013) menetapkan lima komponen pengendalian internal: (1) Lingkungan Pengendalian; (2) Penilaian Risiko; (3) Aktivitas Pengendalian; (4) Informasi dan Komunikasi; dan (5) Pengawasan.

Kredit. Kredit merupakan penyediaan dana oleh pihak yang mempunyai kelebihan dana yang dalam hal ini adalah pihak bank yang kemudian berdasarkan kesepakatan pinjam meminjam bank dengan pihak yang akan meminjam dalam hal ini adalah pihak debitur yang kemudian mewajibkan debitur untuk membayar kembali hutangnya selama jangka waktu sesuai dengan kesepakatan dengan membayar bunga atau pembagian keuntungan berdasrkan perjanjian (Puri, 2012).

Tujuan dan Fungsi Kredit. Penyaluran kredit dari suatu perusahaan mempunyai tujuan tertentu yang tidak lepas dari visi dan misi perusahaan tersebut yaitu: mencari keuntungan; membantu nasabah dalam memperoleh modal dalam pengembangan usahanya; serta membantu pemerintah dalam mensejahterakan rakyatnya, Kasmir (2014 : 116). Selain memiliki tujuan, penyaluran kredit juga mempunyai fungsi. Menurut Kasmir (2014 : 117), kredit memp[unyai beberapa fungsi sebagai berikut :

1. Meningkatkan kegunaan serta peredaran uang.

2. Meningkatkan kegunaan serta peredaran barang.

3. Sebagai alat untuk mestabilkan perekonomian.

4. Meningkatkan gairah usaha bagi masyarakat penerima kredit terutama usaha-usaha kecil.

5. Meningkatkan pemerataan pendapatan masyarakat.

Prosedur Pemberian kredit. Menurut Kasmir (2014) Prosedur pemberian kredit dapat dibagi menjadi beberapa tahap, yaitu:

1. Tahap permohonan kredit.

2. Tahap registrasi serta analisa kredit.

3. Tahap pengambilan keputusan kredit.

4. Tahap realisasi atau pencairan kredit.

5. Tahap penyelesaian atau pembayaran kembali kredit.

Penelitian Terdahulu. Siti Nur'Aeni (2015) dalam penelitian yang berjudul Analisis Penerapan Sistem Informasi Akuntansi Dalam Mendukung Pengendalian Internal Pemberian Kredit. Penelitian ini bertujuan untuk mengetahui bagaimana penerapan sistem informasi akuntansi dapat menunjang pengendalian internal pemberian kredit. Metode yang digunakan dalam penelitian ini adalah deskriptif kualitatif dengan hasil penelitian menyimpulkan bahwa sistem informasi akuntansi yang dilaksanakan sudah baik dan memadai. Tetapi pengendalian internalnya masih kurang memadai.

\section{METODE PENELITIAN}

Jenis Penelitian. Penelitian ini menggunakan metode deskriptif. Didalam penelitian ini penulis menggambarkan bagaimana keadaan atau situasi dari objek penelitian, serta menggambarkan berbagai aspek dari perusahaan yang berhubungan dengan masalah yang dianalisis yang didalamnya meliputi prosedur pemberian kredit usaha mikro serta pengendalian internalnya. 
Tempat dan Waktu Penelitian. Objek dalam penelitian ini adalah PT Bank SulutGo yang beralamat di Jln. Sam Ratulangi No. 9, Manado. Adapun waktu penelitian ini dumulai dari awal Bulan Februari 2018 sampai dengan selesai.

\section{Prosedur Penelitian}

1. Menentukan judul kemudian merumuskan masalah.

2. Melakukan pengumpulan data sesuai dengan masalah yang diangkat.

3. Mengelolah dan menganalisis data yang diperoleh melalui wawancara.

4. Menarik suatu kesimpulan dari masalah yang dianalisis kemudian memberikan saran yang diperlukan.

Jenis dan Sumber Data. Jenis data yang digunakan dalam penelitian ini adalah data Kualitatif. Dimana peneliti mendatangi langsung objek penelitian dan melakukan wawancara langsung untuk memperoleh data dan informasi yang berkaitan dengan masalah yang diteliti. Sedangkan sumber data yang digunakan adalah primer, ini berupa cacatan hasil wawancara yang diperoleh melalui wawancara dengan pihak PT Bank SulutGo bagian pelayan kredit usaha mikro. Dapat juga berupa gambaran umum perusahaan, serta wawancara dengan pimpinan dan karyawan perusahaan mengenai berbagai aktivitas perusahaan serta sumber sekunder ini berupa pengumpulan data dari berbagai sumber baik berupa teks, artikel, maupun berbagai jenis karangan ilmiah, dan catatan-catatan.

Teknik Pengumpulan Data. Teknik pengumpulan data yang dilakukan dalam penelitian ini adalah:

1. Wawancara, yaitu wawancara dilakukan dengan mengajukan pertanyaan kepada Pemimpin departemen kredit dan kepada salah satu Loan Reviewer PT Bank SulutGo.

2. Observasi adalah metode pengumpulan data dengan cara melakukan pengamatan langsung di objek penelitian guna memdapatkan data yang lebih lengkap mengenai gambaran umum PT Bank SulutGo, dan data yang diperlukan untuk penelitian.

Metode analisis. Penelitian ini menggunakan metode deskriptif yaitu data-data yang diperoleh dari proses wawancara maupun observasi, kemudian akan dianalisis. Data yang dianalisis dalam penelitian ini yaitu prosedur pembiayaan kredit usaha mikro dan pengendalian internal pembiayaan kredit kredit usaha mikro pada PT Bank SulutGo. Dari data ini akan dianalisis mengenai apakah penerapan sistem informasi akuntansi pada proses kredit usaha mikro telah menunjang pengendalian internal pembiayaan kredit usaha mikro pada PT Bank SulutGo.

\section{HASIL ANALISIS DAN PEMBAHASAN}

\subsection{Hasil analisis}

\section{Prosedur Pemberian Kredit Usaha Mikro}

Bagan Alur pembiayaan Kredit Usaha Mikro Sejahtera pada PT Bank SulutGo:

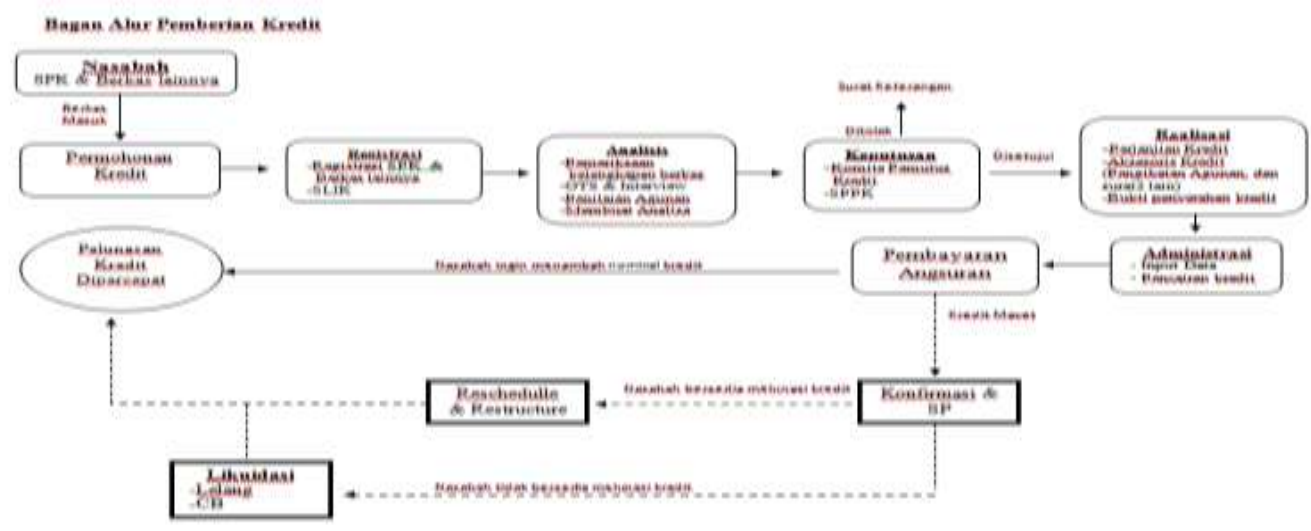




\section{Penjelasan Alur Pembiayaan Kredit Usaha Mikro}

Permohonan Kredit. Permohonan Kredit merupakan tahap pertama dalam alur proses kredit. Ditahap ini, pemohon kredit membuat SPK (Surat Permohonan Kredit) dan harus menyiapkan dokumen yang diperlukan untuk melengkapi dokumen permohonan kredit. Dokumen-dokumen itu adalah:

a. KTP suami dan istri bagi yang sudah menikah.

b. Akta Nikah ( bagi calon debitur yang sudah menikah).

c. KK (Kartu Keluarga).

d. NPWP.

e. Surat keterangan usaha $<$ Rp. 500.000.000.

f. SHM.

g. BPKB

Semua berkas yang dimasukan ini masih berupa foto copy. Bagian operasional kredit PT Bank SulutGo menerima permohonan kredit tersebut, kemudian dilakukan otorisasi oleh manajer pemasaran, lalu dilakukan pemeriksaan kelengkapan berkas oleh account officer. Selain melakukan pemeriksaan kelengkapan berkas, account officer juga yang akan melakukan pengecekan nilai jaminan melalui pemantauan langsung ke tempat usaha maupun jaminan yang menjadi agunan, serta melaksanakan wawancara dengan pihak debitur untuk mengetahui bagaimana karakter dari calon debitur serta mengkomunikasikan kepada debitur mengenai fasilitas kredit yang sesuai dengan kebutuhan calon debitur ini. Untuk kredit usaha mikro sendiri formulir aplikasinya tidak berbeda dengan kredit lainnya hanya dibedakan dengan nominal pinjamannya yaitu dibawah Rp. 500.000.000, karena ini merupakan pinjaman untuk Kredit Usaha Mikro.

Registrasi. Dilakukan registrasi terhadap SPK (Surat Permohonan Kredit) beserta dokumen pendukung lainnya serta melakukan SLIK (Sistem Layanan Informasi Keuangan) dimana ini merupakan sistem layanan untuk mengetahui informasi keuangan dari debitur.

\section{Analisis (Bank Checking)}

a. Pihak bank melakukan wawancara kepada pemohon kredit untuk memperoleh informasi mengenai keaslian data serta menilai bagaimana kepribadian dari pemohon kredit untuk menjadi bahan pertimbangan oleh komite pemutus kredit dalam pengambilan keputusan persetujuan pemberian kredit.

b. Pihak bank melakukan peninjauan langsung dengan cara mendatangi tempat usaha dari pemohon kredit atau calon debitur dengan tujuan untuk mencocokkan berkas pemohon kredit dengan hasil wawancara awal mengenai jaminan kredit.

c. Setelah melakukan wawancara serta peninjauan langsung, maka pihak bank membuat proposal pengajuan kredit yang didalamnya dilampirkan semua dokumen yang telah diserahkan oleh calon debitur serta diuraikan alasan dari pengajuan permohonan kredit oleh calon debitur.

d. Penilaian Agunan merupakan penilaian jaminan yang dilakukan oleh pihak PT Bank SulutGo terhadap agunan atau jaminan yang dijaminkan oleh pemohon kredit dalam mengajukan permohonan kreditnya. Jenis jaminan yang dapat dijaminkan dalam kredit usaha mikro adalah: (1) tanah/bangunan; (2) BPKB kendaraan bermotor; dan (3) surat berharga.

\section{Keputusan}

a. Komite Pemutus Kredit akan melakukan penilaian dan analisa berdasarkan proposal pengajuan kredit dan data yang telah dilampirkan didalamnya kemudian mengambil keputusan apakah permohonan kredit tersebut diterima atau ditolak. Pada PT Bank SulutGo, Komite Pemutus Kredit terdiri dari: (1) Account Officer; (2) Manager Pemasaran; (3) Pemimpin Cabang. 
b. SPPK (Surat Persetujuan Pemberian Kredit) adalah sebuah surat yang isinya menyatakan bahwa permohonan kredit yang diajukan oleh calon debitur kepada PT Bank SulutGo diteriam atau dapat diproses ketahap selanjutnya.

Realisasi. Sebelum kredit direalisasikan, maka pihak bank akan mempersiapkan kelengkapan berkas berupa perjanjian kredit sesuai dengan hasil keputusan rapat komite pemutus kredit. Kelengkapan perjanjian kredit tersebut diproses atau dibuat oleh bagian account officer, kemudian dilanjutkan kepada bagian operasional kredit untuk membuat aksesoris kredit termasuk juga didalamnya mengimput data kredit. Setelah itu, pihak bank akan melakukan pecairan kredit setelah semua kelengkapan berkas dan persyaratan lainnya dilengkapi dan diotorisasi oleh pihak yang berwenang dalam pencairan kredit. Kelengkapaan dokumen yang harus dilampirkan dalam perjanjian kredit adalah sebagai berikut:

a. SPPK (Surat Penegasan Persetujuan Kredit) adalah surat yang diterbitkan oleh Operasional Kredit yang menegaskan bahwa permohonan kredit telah disetujui.

b. Pernyataan kesanggupan membayar kembali pinjaman.

c. Surat pengikatan jaminan.

d. Borgtocht

e. Melakukan input data kredit.

f. Surat perjanjian kredit.

g. Pencairan kredit oleh bank kepada nasabah.

Pembayaran Angsuran. Pembayaran angsuran segera dilakukan nasabah setelah pencairan kredit dilakukan. Nasabah akan menerima jadwal pembayaran angsuran kreditnya dari pihak bank, dan nasabah berkewajiban membayar angsuran sesuai dengan perjanjian yang telah disetujui dalam perjanjian kredit.

Pelunasan Kredit Dipercepat. Hal ini berlaku kepada nasabah yang mempunyai keinginan untuk menambah nominal kreditnya. Pada Bank SulutGo sendiri, percepatan pelunasan kredit bagi nasabah yang ingin menambah nominal kreditnya, mulai berlaku setelah 1 tahun pembayaran angsuran tanpa adanya keterlambatan pembayaran angsuran.

Pengendalian Internal Pembiayaan Kredit Usaha Mikro pada PT Bank SulutGo. Untuk menganalisis pengendalian internal pada pembiayaan kredit usaha mikro yang diterapkan PT Bank SulutGo telah dilaksanakan dengan baik serta sudah sesuai dengan fungsinya, maka proses pengendalian internal dapat diukur melalui lima elemen berikut, yaitu:

1. Lingkungan Pengendalian. PT Bank SulutGo berkomitmen untuk mengelolah sumber daya manusia yaitu dengan cara adanya pelatihan awal atau training bagi pegawai yang baru saja masuk atau bergabung deng PT Bank SulutGo dan pelatihan sesuai dengan posisi atau jabatannya. Ini dilakukan untuk melengkapi kemampuan dasar karyawan dalam melakukan tugasnya. PT Bank SulutGo memiliki struktur organisasi yang menjelaskan pemisahan tanggung jawab serta wewenang kepada pegawainya. Termasuk juga pemisahan wewenang dalam proses pembiayaan kredit untuk melakukan otorisasi dalam pembiayaan. Ini dilakukan untuk menghindari adanya penyalahgunaan wewenang, agar tidak semua pihak bisa melakukan otorisasi atas pembiayaan. Integritas yang dibangun oleh PT Bank SulutGo pada proses pembiayaan kredit usaha mikro yaitu dengan adanya buku pedoman pembiayaan dan proses pemberian kredit yang didalamnya berisi tentang perincian proses pembiayaan dan SOP pemberian kredit yang harus secara dipatuhi oleh semua karyawan yang bertugas dalam proses pembiayaan kredit. Tujuannya adalah agar memperoleh pembiayaan kredit yang sehat. Sedangkan untuk tercapainya nilai etika dalam proses pembiayaan kredit, PT Bank SulutGo menerapkan sanksi yang tegas bagi karyawan yang melanggar aturan atau melakukan pelanggaran yang berakibat merugikan perusahaan. Sanksi tersebut berupa PHK (Pemutusan Hubungan Kerja). Reward dan punishment juga berlaku bagi karyawan pada PT Bank SulutGo,seperti 
memberikan insentif bagi karyawan yang kinerjanya baik, sedangkan diberikan teguran kepada karyawan apabila kinerjanya buruk atau tidak mencapai target.

2. Penaksiran Risiko. Tahap yang paling penting dalam penaksiran risiko dalam proses penyaluran kredit adalah menganalisis serta mengidentifikasi segala kemungkinan dapat terjadinya kesalahan dalam proses kredit yang dapat mengakibatkan kerugian bagi perusahaan. Didalam prosedur penyaluran kredit usaha mikro pada PT Bank SulutGo, analisis kredit adalah tahap yang paling penting dalam proses pembiayaan, kerena melalui tahap ini dilakukan penilaian kelayakan usaha, mengukur berapa besar keperluan keuangan, dan menetapkan bagaimana stuktur pembiayaannya.

3. Aktivitas Pengendalian. Aktivitas pengendalian dilaksanakan oleh PT Bank SulutGo dalam proses pembiayaan kredit dari segi sumber daya manusianya adalah dengan cara adanya pemisahan fungsi. Setiap unit kerja memiliki fungsinya sendiri agar tidak terjadi fungsi ganda atau satu orang melakukan pekerjaan rangkap. Sedangkan aktivitas pengendalian lainnya dalam proses pembiayaan kredit usaha mikro pada PT Bank SulutGo dapat dilihat dari:

a. Adanya berbagai macam dokumen, catatan serta laporan yang harus dipersiapkan baik oleh debitur maupun pihak PT Bank SulutGo dalam proses pembiayaan kredit usaha mikro.

b. Pengawasan serta tinjauan kinerja yang dilakukan oleh pihak Independen, dalam hal ini adalah internal kontrol.

c. Persetujuan dan otorisasi.

4. Informasi dan Komunikasi. PT Bank SulutGo menggunakan sistem online dalam proses pembiayaan kredit usaha mikro. Sistem informasi yang digunakan dalam proses pemberian kredit adalah SLIK (Sistem Layanan Informasi Keuangan) dimana pada saat calon nasabah mengajukan permohonan kredit dan telah melengkapi dokumen, maka bagian operasional kredit akan melakukan registrasi dan SLIK. Apabila dari hasil pemeriksaan riwayat calon nasabah baik, maka bagian Account Officer akan memeriksa kelengkapan berkas, melakukan wawancara, meninjau langsung ke tempat usaha, membuat analisa dan proposal. Kemudian dilanjutkan ke manajer pemasaran untuk membuat disposisi dan mengajukan proposal pembiayaan kredit ke Pimpinan Cabang. Proposal inilah yang akan menjadi informasi bagi komite pemutus kredit dalam pertimbangan pengambilan keputasan kredit.

5. Pengawasan (Monitoring). Pengawasan merupakan komponen pengendalian internal yang kelima untuk memastikan bahwa operasional pembiayaan kredit usaha mikro pada PT Bank SulutGo dilaksanakan sesuai dengan SOP yang berlaku dalam perusahaan dari mulai prosedur pembiayaan, akad hingga tahap pelunasan, maka PT Bank SulutGo telah memiliki institusi internal independen yang khusus dalam pengawasan kepatuhan, yaitu internal kontrol.

\subsection{Pembahasan}

\section{Penerapan Sistem Informasi Akuntansi Pembiayaan Kredit Usaha Mikro pada PT Bank SulutGo}

Sumber Daya Manusia. Semua pegawai yang ada di PT Bank SulutGo pada kegiatan operasional pembiayaan kredit usaha mikro sebelumnya telah diberikan pelatihan serta pendidikan perbankan, dan setiap karyawannya harus memahami SOP pembiayaan kredit usaha mikro yang diterapkan oleh perusahaan. Karyawan yang ada di PT Bank SulutGo juga sudah dibagi sesuai dengan tanggung jawab masing-masing yang digambarkan dalam bentuk struktur organisasi. Pembagian tugas ini berdasarkan kemampuan dan kompetensi dari masing-masing individu yang ada di perusahaan, sehingga dengan demikian diharapkan perusahaan dapat berjalan sesuai dengan harapan dan tujuan yang telah ditetapkan oleh perusahaan. 
1. Alat. Dari penelitian yang dilakukan, menunjukan alat yang digunakan PT Bank SulutGo didalam membantu operasional perusahaan dan dalam penerapan sistem informasi akuntansi pembiayaan kredit usaha kecil adalah sebagai berikut: (a) Komputer; (b) Telepon kantor: (c) Printer; (d) Mesin penghitung uang; dan (e) CCTV. Dengan penggunaan komputer dan printer sebagai salah satu unsur dalam sistem informasi akuntansi pembiayaan kredit pada PT Bank SulutGo, ini sangantlah membantu bagi para karyawan dalam mempercepat proses pemberian kredit dalam hal ini memproses semua data dan laporan. Semua peralatan ini sangat membantu mempermudah jalannya proses pemberian kredit.

2. Catatan. Berbagai catatan yang diperoleh dalam proses pembiayaan kredit usaha mikro pada PT Bank SulutGo diantaranya yaitu berupa jurnal kredit dan tabungan. Ini adalah salah satu bentuk usaha dari PT Bank SulutGo dalam melaksanakan pengendaliannya terhadap setiap proses transaksi. Ini dilakukan guna menghindari berbagai kemungkinan kesalahan dan penyelewengan dan yang bisa saja terjadi karena kelalaian dari karyawannya.

3. Laporan. Laporan yang dibuat oleh PT Bank SulutGo dalam proses pemberian kredit adalah laporan dalam bentuk proposal. Laporan tersebut menjadi bahan bagi manajemen kredit dalam proses pengambilan keputusan dan merupakan bahan bagi manajemen dalam meninjau dan mengevaluasi setiap proses pembiayaan kredit dan juga menjadi salah satu langkah manajemen maupun perusahaan dalam melaksanakan pengendaliannya.

4. Formulir. Formulir yang digunakan dalam proses pembiayaan kredit usaha mikro telah sesuai dengan standar perusahaan dan setiap formulir harus diotorisasi oleh pejabat kredit yang berwenang. Ini dapat menjadi salah satu cara bagi pihak bank dalam melakukan pengendaliannya selama proses pembiayaan kredit.

5. Prosedur. PT Bank SulutGo memiliki beberapa tahap prosedur pembiayaan dimulai dari Tahap registrasi, analisis kredit, keputusan kredit, realisasi kredit, administrasi, pemantauan kredit, serta pelunasan/pembayaran kredit. Prosedur tersebut terdapat pada Buku Pedoman Pelaksanaan Pemberian Kredit Mikro/Kecil Sejahtera Bank Sulut yang telah sesuai penyusunannya dengan kebijakan pembiayaan oleh Bank Indonesia, yang didalamnya terdapat SOP (Standart Operational Procedure) pembiayaan kredit bagi karyawan dalam melaksanakan setiap proses pembiayaan kredit usaha mikro. Dengan dijalankannya setiap prosedur menurut SOP yang berlaku pada perusahaan, maka pengendalian internal pembiayaan kredit usaha mikro juga dipenuhi.

Penerapan Sistem Informasi Akuntansi Dalam Menunjang Pengendalian Internal Pembiayaan Kredit Usaha Miko. Berdasarkan hasil penelitian, ditemukan bahwa penerapan sistem informasi akuntansi pembiayaan kredit usaha mikro pada PT Bank SulutGo diukur dari unsur-unsur sistem informasi akuntansi telah mendukung setiap karakteristik pengendalian internal dari pembiayaan kredit usaha mikro pada PT Bank SulutGo.

1. Sumber Daya Manusia - Lingkungan Pengendalian. Dengan pelatihan yang diberikan oleh PT Bank SulutGo dalam rangka meningkatkan kualitas sumber daya manusia serta pembagian tugas dan tanggung jawab yang jelas melalui struktur organisasi, dapat menunjang pengendalian internal terutama pada komponen lingkungan pengendalian. Jadi, dari penjelasan diatas dapat disimpulkan bahwa usur sumber daya manusia dalam sistem informasi akuntansi menunjang pengendalian internal terutama pada komponen lingkungan pengendalian.

2. Alat - Aktivitas Pengendalian dan Monitoring. Dengan adanya peralatan yang digunakan oleh PT Bank SulutGo ini merupakan salah satu usaha perusahaan dalam menunjang pengendalian internalnya terutama menunjang komponen aktivitas pengendalian dan monitoring. Ini digambarkan dengan adanya komputer dan printer 
membantu dalam mempercepat proses pembuatan berbagai dokumen dalam proses pembiayaan kredit, dan membantu menyimpan dokumen dalam komputer. Telepon kantor membantu pegawai dalam berkomunikasi yaitu menghubungi debitur dalam memberikan informasi. Serta CCTV yang membantu pengendalian internal dalam hal monitoring. Dengan adanya CCTV, maka perusahaan dapat melakukan monitoring kepada pegawainya selama operasional perusahaan.

3. Catatan, Formulir, Laporan - Aktivitas Pengendalian serta Informasi dan Komunikasi. Unsur catatan, laporan, dan formulir dalam sistem informasi akuntansi, menunjang pengendalian internal dari segi informasi dan komunikasi serta aktivitas pengendalian. Ini digambarkan dengan adanya catatan, formulir, dan laporan yang baik maka informasi yang dibutuhkan dalam pengambilan keputusan juga akan baik dan tepat. Sedangkan dikatakan menunjang aktivitas pengendalian karena, dengan adanya catatan, formulir, serta laporan selama proses pembiayaan kredit, maka informasi yang dihasilkan guna dalam pengambilan keputusan juga bisa dipertanggung jawabkan.

4. Prosedur - Penaksiran Risiko. Prosedur pemberian kredit dalam unsur sistem informasi akuntansi menunjang pengendalian internal dilihat dari segi penaksiran risiko. Ini terjadi karena dalam setiap tahap proses pemberian kredit membutuhkan analisa yang baik dari pihak bank dalam menilai keuangan serta usaha dari debitur agar dapat meminimalisir risiko kemungkinan terjadinya kredit macet dimasa yang akan datang.

\section{KESIMPULAN DAN SARAN}

\subsection{Kesimpulan}

Berdasarkan uraian hasil penelitian serta pembahasan yang telah diuraikan diatas, maka kesimpulanya adalah sebagai berikut:

1. Penerapan sistem informasi akuntansi pembiayaan kredit usaha mikro pada PT Bank SulutGo telah dilaksanakan dengan baik serta sudah sesuai dengan ketetapan yang berlaku diperusahaan. Ini dapat dilihat dari sudah terpenuhinya karakteristik sistem informasi akuntansi dalam pembiayaan kredit usaha mikro pada PT Bank SulutGo.

2. Sistem informasi akuntansi telah diterapkan dengan baik dan telah menunjang pengendalian internal pembiayaan kredit usaha mikro pada PT Bank SulutGo. Ini digambarkan dalam unsur-unsur sistem informasi akuntansi yang menunjang pengendalian internal sebagai berikut:

a. Dengan adanya beberapa bagian yang terlibat dalam proses pembiayaan kredit usaha mikro pada PT Bank SulutGo telah menunjang pengendalian internal dari segi lingkungan pengendalian.

b. Semua dokumen yang di persiapkan oleh calon debitur dan yang dibuat selama proses pemberian kredit telah menunjang pengendalian internal pemberian kredit dari segi aktivitas pengendalian dan informasi.

c. Setiap tahap dalam prosedur pembiayaan kredit telah menunjang semua komponen dalam pengendalian internal pemberian kredit usaha mikro pada PT Bank SulutGo.

\subsection{Saran}

Berdasarkan analisis yang telah dilakukan terhadap penerapan sistem informasi akuntansi dalam menunjang pengendalian internal pembiayaan kredit usaha mikro di PT. Bank SulutGo, diketahui bahwa PT Bank SulutGo sudah menerapkan sistem informasi akuntansi serta pengendalian internal yang baik atas pembiayaan kredit usaha mikro. PT. Bank SulutGo harus mempertahankannya agar dapat meminimalisir terjadinya kesalahan dalam proses pembiayaan kredit usaha mikro. 


\section{DAFTAR PUSTAKA}

Bahri, Syaiful. 2016. Pengantar Akuntansi. Penerbit Andi. Yogyakarta.

Indrawan, dan Poppy Yuniawati. 2014. Metodologi Penelitian. Jakarta: Refika Aditama. Kasmir. 2014. Dasar-Dasar Akuntansi. Edisi Revisi. Jakarta: PT. Raja Grafindo Persada Krismiaji. 2015. Sistem Informasi Akuntansi. Edisi keempat. Yogyakarta: UPP-STIM YKPN Mutia, Nova Gina. 2015. Analisis Penerapan Sistem Informasi Akuntansi Dalam Menunjang Efektivitas Pengendalian Internal Pembiayaan MuraBahah. el-JIZYA Jurnal Ekonomi Islam (Islamic Economics Journal) Vol.4, No.2 Juli - Desember 2016 ISSN $2354-905 X$.

Romney, Marshall B. dan Paul John Steinbart. 2014. Sistem Informasi Akuntansi. Edisi 13. Jakarta: Salemba Empat

Romney, Marshall B. 2015. Sistem informasi akuntansi (terjemahan: Kikan Sakinah Nur Safira dan Novita Puspasari). Edisi 13. Jakarta: Salemba Empat.

Siti Nur'Aeni. 2015. Analisis Penerapan Sistem Informasi Akuntansi Dalam Mendukung Pengendalian Internal Pemberian Kredit Pada PT Bank Danamon Indonesia (Persero), Unit Puger Cabang Jember. http://repository.unmuhjember.ac.id/189/2/ARTIKEL\%20JURNAL.pdf Diakses tanggal 9 Mei 2018

Sugiyono. 2015. Metode Penelitian Pendidikan. Bandung: Alfabeta.

www.banksulutgo.co.id Diakses Tanggal 3 April 2018

Yuliawati, Reni. 2017. Peranan Sistem Informasi Akuntansi Dalam Menunjang Efektivitas Pengendalian Internal Pemberian Kredit. Artikel Skripsi Universitas Nusantara PGRI Kediri.

http://simki.unpkediri.ac.id/mahasiswa/file_artikel/2017/12.1.02.01.0208.pdf. Di akses Tanggal 1 juni 2108 